\title{
Conception and development of the Fetal Tissue Bank
}

\author{
SYLVIA D LAWLER* \\ From the Department of Cytogenetics and Immunogenetics, Institute of Cancer Research and The Royal \\ Marsden Hospital, Fulham Road, London SW3 6JJ, UK
}

The Fetal Tissue Bank is financed by a Special Project Grant from the Medical Research Council. It is located at the Royal Marsden Hospital, Fulham Road, in the Department of Cytogenetics and Immunology, and its purpose is to collect dead fetuses for dissection and to distribute the tissues. The Bank is located in a cancer hospital because it was founded by Humphrey Kay in 1957 with the idea of providing supplies of human fetal tissue for transplantation to patients with leukaemia. The demands for fetal tissue have changed and expanded; thus the Bank now supplies material for diverse activities. It is used by virologists, oncologists of various disciplines, and geneticists as well as by clinicians.

\section{Organisation of the Bank}

The successful operation of the Bank has been maintained because of the collaboration of many obstetricians. Fetuses are collected within the London area and brought back to the hospital as rapidly as possible for immediate dissection by surgical theatre techniques in a 'sterile' room. Certain clinical data are obtained, in particular the date of the last menstrual period before the termination of pregnancy. Each fetus is given a number, and the tissues are distributed, the names of the recipients being recorded. There is an answerphone service.

\section{Source of fetuses}

Table 1 shows the method of termination of pregnancy for the fetuses received between 1957 and 1979. When the Bank was founded, the operation of hysterotomy was being performed regularly, and the number of fetuses received from this source increased each year until 1968, since when the number has continued to decline steadily. The tissues of fetuses obtained by hysterotomy are particularly suitable for investigations requiring a source of

*Director, Fetal Tissue Bank
Table 1 Method of termination of pregnancy for fetal tissues received by the Fetal Tissue Bank

\begin{tabular}{|c|c|c|c|c|c|}
\hline Year & Hysterotomy & $\begin{array}{l}\text { Other } \\
\text { abortions }\end{array}$ & $\begin{array}{l}\text { Prostaglandin } \\
\text { induction }\end{array}$ & Suction & Total \\
\hline $\begin{array}{l}1957 \\
\text { (5 Sept- } \\
31 \text { Dec) }\end{array}$ & 7 & 17 & & & 24 \\
\hline 1958 & 50 & 88 & & & 138 \\
\hline 1959 & 108 & 145 & & & 253 \\
\hline 1960 & 142 & 152 & & & 294 \\
\hline 1961 & 178 & 207 & & & 385 \\
\hline 1962 & 179 & 122 & & & 301 \\
\hline 1963 & 199 & 57 & & & 256 \\
\hline 1964 & 237 & 67 & & & 304 \\
\hline 1965 & 297 & 114 & & & 411 \\
\hline 1966 & 441 & 72 & & & 513 \\
\hline 1967 & 542 & 1 & & & 543 \\
\hline 1968 & 757 & 0 & & & 757 \\
\hline 1969 & 725 & 1 & & & 726 \\
\hline 1970 & 620 & 0 & & & 620 \\
\hline 1971 & 529 & 0 & & & 529 \\
\hline 1972 & 349 & 3 & 50 & & 402 \\
\hline 1973 & 307 & 1 & 109 & & 417 \\
\hline 1974 & 198 & 7 & 490 & & 695 \\
\hline 1975 & 152 & 0 & 535 & 26 & 713 \\
\hline 1976 & 57 & 5 & 383 & 228 & 673 \\
\hline 1977 & 51 & 1 & 130 & 690 & 872 \\
\hline 1978 & 20 & 0 & 163 & 857 & 1040 \\
\hline 1979 & 11 & 0 & 209 & 1771 & 1991 \\
\hline
\end{tabular}

* This column includes spontaneous abortions and terminations of pregnancy by techniques other than the prostaglandin infusion or suction methods.

viable cells. Gradually medical induction became a method of choice for the termination of pregnancy, and early in the 1970s, prostaglandins began to be used for this purpose. Fetuses obtained after a prostaglandin termination were first collected in 1972, and the number increased until 1976. The number of these fetuses that we now collect is a reflection of the usefulness of the tissue to the users. Tissue cultures using organs obtained from fetuses after a medical induction produce only a limited yield of viable cells. It therefore became apparent in the early 1970s that, if the Bank were to continue to meet its commitments, some other source of tissue would have to be found. This was why a pilot study was made to see whether organs could be identified in the disrupted fetuses obtained from terminations 
of pregnancy by the suction method. ${ }^{1}$

We started to dissect disrupted fetuses in 1975, since when the number collected has steadily increased. The development of this technique has enabled virologists to continue to use human fetal tissues for the isolation of viruses and the preparation of vaccines.

\section{Ethical considerations}

In 1970 an advisory group, with Sir John Peel as chairman, was appointed by the Secretary of State for Social Services and the Secretaries of State for Scotland and Wales to consider the ethical, medical, social, and legal implications of using fetuses and fetal material for research. This group took extensive evidence from the Medical Research Council and other organisations. A report was published in $1972^{2}$ giving a recommended code of practice for the use of fetuses and fetal material in research. This report recommended that all research using the fetus, fetal tissue, or fetal material should be approved by an appropriate committee in the institution in which the research was undertaken, and that this committee should accept responsibility for ensuring that such investigations were ethical.

In the Fetal Tissue Bank, although it is not legally binding, we have followed the tenets of the 'Peel Report'. All users of the bank have to sign an ethical clearance form:

'I $\ldots \ldots \ldots \ldots \ldots \ldots$ certify that the research on human fetal material for which I am responsible has been approved by my local Ethical Committee or equivalent body.

Signed $\ldots \ldots \ldots \ldots \ldots \ldots \ldots \ldots \ldots \ldots \ldots \ldots \ldots$

Date .....................

and the function of the Fetal Tissue Bank in the Royal Marsden Hospital has been sanctioned by the Ethical Committee of the Royal Marsden Hospital.

The tenets of the 'Peel Report' that are relevant to the operation of the Fetal Tissue Bank, and to which we adhere, are as follows:

'The minimal limit of viability for human fetuses should be regarded as 20 weeks' gestational age. This corresponds to a weight of approximately 400 500 grammes.

The use of the whole dead fetus or tissues from dead fetuses for medical research is permissible subject to the following conditions:

(i) The provisions of the Human Tissue Act are observed;

(ii) Where the provisions of the Human Tissue Act do not apply there is no known objection on the part of the parent who has had an opportunity to declare any wishes about the disposal of the fetus;

(iii) Dissection of the dead fetus or experiments on the fetus or fetal material do not occur in the operating theatre or place of delivery;

(iv) There is no monetary exchange for fetuses or fetal material;

(v) Full records are kept by the relevant institution.'

\section{Estimation of fetal age}

It is always important to know the age of the fetal tissue, whether it is being used for clinical purposes or for research. The age of the fetus may be expressed as menstrual age or gestational age. The starting point for menstrual age is the first day of the last menstrual period. Others prefer to use gestational age, which begins 14 days after the start of the last menstrual period. When a menstrual cycle is not 28 days in length, the estimated gestational age is from 14 days before the next anticipated menstruation. $^{3}$ Whichever measurement is used, there is inherent risk of inaccuracy because errors of recall can occur.

Data on fetal measurements correlated with the reported menstrual dates have been used in the Fetal Tissue Bank in order to give an assessment of the age of the fetus. When whole fetuses are available, the crown-rump length is the measurement of choice, and we use the simple formula that the crown-rump length in centimetres +4 is equivalent to menstrual age in weeks.

When we started using disrupted fetuses we decided to use the length of foot as the fetal measurement. Foot length was compared with crown-rump length by using whole fetuses, as shown in the Figure. The estimates of menstrual age based on foot length now in use in the Fetal Tissue Bank are shown in Table 2.

\section{Non-clinical uses of fetal tissue}

In a typical month, for example, July 1980, we received 173 disrupted fetuses, of which 107 were discarded because no organs were identified. From the remaining 66 fetuses with identifiable organs, 327 specimens of tissue were distributed, and from the 28 prostaglandin-induced abortions of whole fetuses, 206 specimens of tissue were distributed. The service that the Fetal Tissue Bank provides can be summarised in tabular form (Table 3).

The tissues from the disrupted fetuses are suitable for cell investigations and are essential for the tissue cultures needed in virological studies. Tissues from prostaglandin induction are suitable for the work on oncofetal antigens, since they can be used in the 


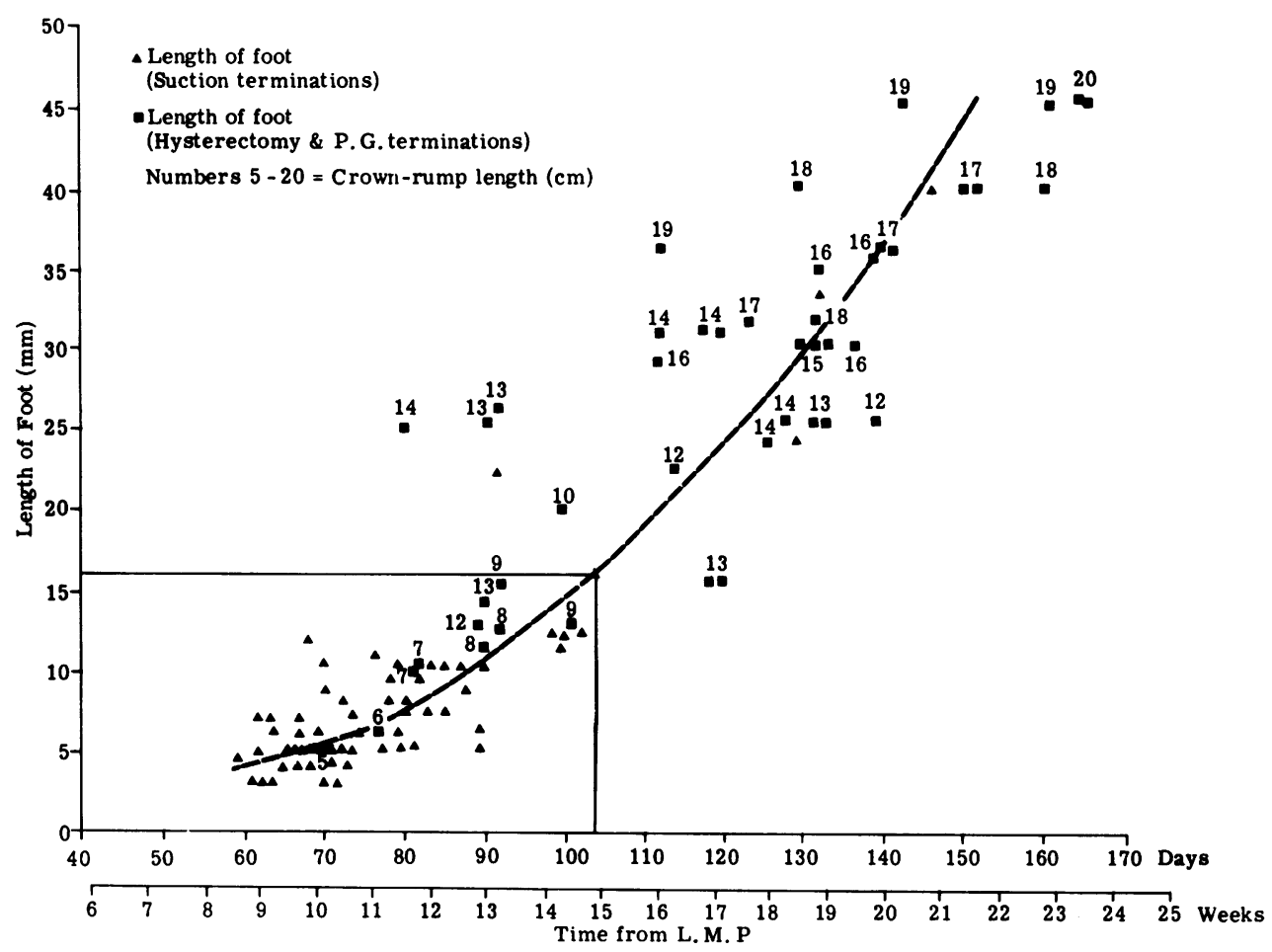

The gestation time of suction terminations can be estimated from the length of a foot.

The gestation time of an intact fetus is estimated by crown-rump length.

Correlation between crown-rump and foot lengths and their relation to gestation time: $P G=$ prostaglandin.

[This figure appeared in the Lancet of 22 January 1977, page 187.]

Table 2 Foot length and menstrual age

\begin{tabular}{ll}
\hline Length of foot $(\mathrm{mm})$ & Age (weeks) \\
\hline 2 & $8 \frac{1}{2}$ \\
3 & 9 \\
4 & $9 \frac{1}{2}$ \\
5 & 10 \\
6 & $10 \frac{1}{2}$ \\
7 & 11 \\
8,9 & $11 \frac{1}{2}$ \\
10 & 12 \\
11 & $12 \frac{1}{2}$ \\
12 & 13 \\
13,14 & $13 \frac{1}{2}$ \\
15,16 & 14 \\
17 & $14 \frac{1}{2}$ \\
18,19 & 15 \\
20,21 & $15 \frac{1}{2}$ \\
22 & 16 \\
\hline
\end{tabular}

preparation of antigens and for the absorption of antibodies prepared against tumour products. There is always the possibility that an antibody prepared against a tumour antigen absorbed with adult tissue may still react with an antigen present during development.

\section{Table 3 Non-clinical uses of fetal tissue}

\begin{tabular}{|c|c|c|}
\hline Field of study & Investigation & Examples of tissues used \\
\hline Virology & $\begin{array}{l}\text { Isolation of virus. } \\
\text { Preparation of vaccines }\end{array}$ & $\begin{array}{l}\text { Liver, lung, kidney, } \\
\text { nasal mucosa }\end{array}$ \\
\hline Cancer research & Oncofetal antigens & $\begin{array}{l}\text { Brain, liver, breast, } \\
\text { pancreas, thymus }\end{array}$ \\
\hline $\begin{array}{l}\text { Biochemical } \\
\text { genetics }\end{array}$ & $\begin{array}{l}\text { Development of } \\
\text { isoenzymes. Inborn } \\
\text { errors of metabolism }\end{array}$ & $\begin{array}{l}\text { Liver, lung, brain, heart, } \\
\text { kidneys, placenta, } \\
\text { muscle }\end{array}$ \\
\hline $\begin{array}{l}\text { Endocrinology } \\
\text { Haematology }\end{array}$ & $\begin{array}{l}\text { Sources of hormone } \\
\text { Fetal haemopoiesis }\end{array}$ & $\begin{array}{l}\text { Adrenal, lung } \\
\text { Liver, bone-marrow, } \\
\text { spleen, thymus }\end{array}$ \\
\hline $\begin{array}{c}\text { Molecular } \\
\text { biology }\end{array}$ & $\begin{array}{l}\text { Preparation of messenger } \\
\text { ribonucleic acid }\end{array}$ & Liver, muscle \\
\hline $\begin{array}{l}\text { Developmental } \\
\text { biology }\end{array}$ & $\begin{array}{l}\text { Sex differences in man. } \\
\text { Blood group systems }\end{array}$ & Gonads \\
\hline $\begin{array}{l}\text { Cellular } \\
\text { biology }\end{array}$ & $\begin{array}{l}\text { Study of trophoblast } \\
\text { receptor mechanisms }\end{array}$ & Placenta, muscle, brain \\
\hline Immunology & $\begin{array}{l}\text { Preparation and } \\
\text { absorption of } \\
\text { monoclonal and other } \\
\text { antibodies }\end{array}$ & $\begin{array}{l}\text { Brain, pancreas, breast, } \\
\text { liver, thymus }\end{array}$ \\
\hline
\end{tabular}




\section{Clinical uses of fetal tissue}

BIOLOGY OF FETAL THYMUS

In a preliminary communication in 1961,4 Miller described the effect of neonatal thymectomy in mice and proposed that the thymus at an early stage in life plays an important role in the immunological response. He also produced evidence that engrafting a thymus restored the capacity to reject allogeneic skin grafts, which was one of the functions lost by the neonatally thymectomised mice. In $1962^{5}$ Miller gave more details of these experiments when he concluded that during very early life the thymus 'produces the progenitors of immunologically competent cells which subsequently mature and migrate to other sites'. His experiments, however, did not exclude the possibility that the young thymus produces a humoral factor that is necessary for the maturation of lymphocytes elsewhere in the body.

Also in 1962, Kay et al. ${ }^{6}$ described the development of the thymus in the human fetus and discussed its relation to immunological potential. They recorded the weights of human fetal thymuses in relation to crown-rump length and body weight. They inferred that the thymus grows regularly during the first two trimesters but that the growth rate levels off at the beginning of the third trimester. After that, growth rate declines until birth and continues to do so thereafter. The initial up-gradient from 12 to 24 weeks was deduced from information collected in the Fetal Tissue Bank, but the data on older fetuses were obtained from the literature. The data on the older fetuses may have been less accurate because of the way in which they were collected, and also because the thymus could have undergone involution during the delay between death and delivery of the fetus. The authors compared the growth of the spleen with that of the thymus and found that the spleen lagged behind the thymus in growth, but that the increase in relative splenic weight continued until birth.

In comparing the three aspects of lymphoid maturation that can be subjected to quantitative analysis, namely, the development of spleen, thymus, and blood lymphocytes, Kay et al. ${ }^{6}$ found that these data from the human source were compatible with the hypothesis that cells from the thymus colonise the other lymphoid tissues of the body. Thus, by deduction in man, the same conclusion was reached as that from the experimental approach in mice.

\section{IMMUNODEFICIENCY IN INFANCY}

Syndromes diagnosed in infancy, attributable to a failure of the development or function of the immune system, have been recognised since 1950 . At first the immunological deficiencies were described as humoral immunity, cellular immunity, or both. The transplantation of fetal tissue came to play a role in the treatment of some of these immunological deficiencies.

The immune deficiency that is associated with the lack of gammaglobulins was described by Bruton in 1952. ${ }^{7}$ Once the diagnosis was made, treatment with gammaglobulin was used to control the infections that are the salient features of the disease, which is inherited as a sex-linked recessive.

\section{'Swiss type' agammaglobulinaemia}

In the next few years variants of this humoral disorder were described, and one of these, which came to be known as the 'Swiss' form of agammaglobulinaemia, had been described by Glanzmann and Riniker in $1950 . .^{8}$ This syndrome was defined by severe lymphopenia, absence of all immunoglobulins, hypoplasia of the lymphoreticular system, and an autosomal recessive inheritance pattern. Nowadays the term combined immunodeficiency is used to describe immune disorders in which there is a deficiency of both antibody responses and cellmediated immunity.

In 1965 Hitzig et al. ${ }^{9}$ described an attempt to treat two patients with the 'Swiss form of agammaglobulinaemia' by implanting human fetal thymuses which had been collected in the Fetal Tissue Bank. In both children a transient improvement in lymphocyte count was seen, but both died later of pulmonary infection.

Two earlier attempts at immunological reconstitution with thymus grafts in lymphopenic patients had also been clinically unsuccessful. In a case of alymphocytosis and agammaglobulinaemia, Rosen et al. ${ }^{10}$ used the thymic tissue from a 5-month-old infant, but this did not populate the lymphoid tissue of the recipient. Harboe 11 made the important observation that in a 5-month-old boy with hypogammaglobulinaemia and severe lymphocytopenia, thymus implantation induced the formation of a monoclonal gamma-G and a monoclonal gamma-M antibody, but the patient died of pneumonia two months later.

In 1968 Hong et al.12 reported the successful treatment of an 8-month-old boy with (Swiss type) immunological deficiency complicated by oral moniliasis. The presence of cells with a female karyotype in the bone-marrow established the engraftment. Unfortunately, the cells of the graft reacted against those of the host, producing a characteristic skin eruption, one of the signs of graft-versus-host disease. The patient died of pneumonia. The lessons learned from this case were that although thymus graft alone is not sufficient to restore immune function in patients with combined 
immunodeficiency, the attempt to supply stem cells from fetal thymus involves the risk of graft-versushost disease. It had been thought that the use of fetal cells could circumvent the hazard of transplanting immunocompetent tissue. The fetuses used were 12week menstrual age, and it appears that even at this early stage fetal cells can already react immunologically.

The recognition of an immune deficiency which can be treated by implantation of fetal thymus postdated these earlier discouragements.

\section{DiGeorge syndrome}

In 1968 DiGeorge, ${ }^{13}$ having studied four infants, defined a clinical syndrome in which congenital absence of the thymus is associated with other abnormalities, particularly absence of the parathyroid glands. Although the syndrome came to be known as the DiGeorge syndrome, DiGeorge himself disclaimed priority in describing congenital absence of the thymus by referring to a description of a case in a letter in the London Medical Gazette by Harington in 1829.14 The important point made by DiGeorge concerning the syndrome was that, for the first time in man, it demonstrated that cellular immunity cannot be achieved in the absence of thymic factors, even if peripheral blood lymphocyte counts and levels of immunoglobulins are normal. Affected children are deficient in rejection of skin allografts and fail to manifest delayed hypersensitivity reactions to common antigens such as monilia.

In 1968 two case reports appeared simultaneously in the Lancet describing the implantation of fetal thymus and the restoration of immunological competence in patients with the DiGeorge syndrome. In neither case were there problems with graft-versushost disease. After the implant the lymphocytes responded to phytohaemagglutinin (PHA), which they had failed to do before. Thus it was evident that an intact thymus was required for the PHA response. ${ }^{15} 16$

Two years later August et al. ${ }^{17}$ reported the follow-up clinical and immunological studies on their patient with DiGeorge syndrome who had received a fetal thymic implant. They demonstrated the persistence for 16 months of the improvement in cellular immune functions, as measured by delayed hypersensitivity, skin graft rejection, and the response of the lymphocytes to PHA. An even longer follow-up has been recorded on the patient of Cleveland et al. ${ }^{16}$ The child had received the fetal thymic transplant at the age of 7 months, and at the age of 6 years the restoration of immune function persisted and the child, although mentally retarded, had no unusual infections. ${ }^{18}$

Until 1975 the implantation of fetal thymus in patients with DiGeorge syndrome offered the best hope of improving the deficient cellular immune function.

\section{Thymic factors}

The rapid restoration of cell-mediated immunity after a thymic transplant and the failure to detect the presence of donor lymphocytes in cases of DiGeorge syndrome ${ }^{19}$ and other types of $\mathrm{T}$-cell deficiency ${ }^{20}$ suggested that the transplanted thymuses were supplying humoral factors necessary for the maturation of $\mathrm{T}$ cells. The purification and characterisation of the first thymic polypeptide hormone (thymosin) was achieved by Goldstein et al. in 1972.21

The observation that the number of rosettes with sheep red cells (E-rosettes), a measure of T-cell activity, formed by the lymphocytes from some immunodeficient patients could be increased by the addition of thymosin led to the development of an assay for thymosin 22 and to identification of patients deficient in thymosin. ${ }^{23}$ Thymosin increases the number of E-rosettes formed by the lymphocytes from patients with thymic hypoplasia and the DiGeorge syndrome but it does not affect the capacity to form E-rosettes in patients with severe combined immunodeficiency where the defect is at the stem cell level. The E-rosette assay can therefore be used to identify patients whose immune deficiency is likely to respond to thymosin. Nowadays, only if there is no response to thymosin does the use of a fetal thymus need to be considered in the treatment of T-cell deficiency.

\section{Severe combined immunodeficiency}

Severe combined immunodeficiency disease (SCID) is the term now used to describe the heterogeneous group of congenital disorders that are thought to be the consequence of a defect of lymphoid cells. There are defects in both the thymus dependent (T-cell) and thymus independent (B-cell) lymphocyte populations. The treatment of choice for SCID is now bone-marrow transplantation from an HLA compatible donor. Unfortunately, patients do not always have a suitable HLA compatible donor, and so the use of fetal liver cells, as a source of stemcells, remains an option that must be considered. The problems that have to be circumvented are failure of engraftment and the development of graftversus-host disease.

In a review article about the usefulness of fetal liver transplantation in SCID, Lowenburg ${ }^{24}$ collated the reported cases. Twenty-nine infants with SCID had been treated unsuccessfully with 39 liver transplants, but some of the patients died so soon after the transplantation that the success of the engraftment could not be evaluated. 
One factor that has to be considered is that cases of SCID form such a heterogeneous clinical group. Within this group of diseases one entity has been defined on the basis of a biochemical defect. The immunological deficiency has been associated with the absence of the enzyme adenosine deaminase (ADA), which is essential for the successful formation of lymphocytes. ${ }^{25}$ Cases of ADA deficiency have been corrected by repeated blood transfusion ${ }^{26}$ whereby the enzyme is passively transferred.

Lowenburg ${ }^{24}$ tabulated the clinical and immunological data on six successful fetal liver transplants. Three of these cases had been published elsewhere ${ }^{27-29}$ but the other three were unpublished cases, described at the Third Workshop of the International Cooperative Group for Bone-marrow Transplantation in Man (combined immunodeficiency) held at Tarrytown, USA, in 1976. The proceedings of this meeting have not been published. These six patients were aged between 3 and 22 months; two were ADA negative, the others positive. Fresh fetal liver cells were used in all cases, which is an important point, because among the cases where engraftment failed, cells recovered after cryopreservation had been used in some cases. This demonstrates the need for special care in the preservation and recovery of cells, including careful monitoring of the viability of the cells administered. Consideration has been given to the optimal age of fetal tissue administered and the consensus seems to be that the younger the fetus, the better. The donor fetuses in the successful cases were almost all less than 12 weeks old. Buckley ${ }^{29}$ suggested that 'younger fetal livers may be more effective because of their relative enrichment for haematological stem cells as compared to liver of older gestational age'. In successful cases, the number of cells administered per $\mathrm{kg}$ body weight was often lower than in the unsuccessful cases, so cell numbers may not be a critical factor. Intraperitoneal administration of the cells was used in the successful cases. Some of the cases had repeated transplantations before reconstitution was achieved, which is in accord with what happens with bone-marrow transplantation where more than one transplant may also be required. ${ }^{30}$

Recently, a case has been made for the use of fetal liver and thymus for immunological reconstitution of patients, with variants of SCID, who do not have a suitable bone-marrow donor. ${ }^{31}$ These variants of SCID require both a source of stem cells and a source of thymic factors for successful immunological reconstitution.

APLASTIC ANAEMIA

Since fetal liver provides a source of bone-marrow stem cells, a relevant question is whether it can be used for transplantation in cases of haemopoietic disorders. As early as 1961 Bodley Scott et al. ${ }^{32}$ reported 14 cases with different types of bonemarrow hypoplasia who had been treated by the injection of fetal haemopoietic cells. Out of four cases of chronic pancytopenia, two had remissions, and the timing of these suggested that the fetal cells may have played a role, even though chimaerism was not detected.

The use of fetal liver for transplantation in cases of aplastic anaemia has now been superseded by the use of allogeneic bone-marrow from HLA-matched donors, child or adult. However, there still remains the problem of the case where no suitable living donor is available. Recently, interest has revived in this application of human fetal liver, and the Fetal Tissue Bank has supplied fetal liver to Dr E Gluckman and her colleagues for this purpose. ${ }^{33}$ Implants of human fetal liver were attempted in four children aged 4 to 13 years who had severe bonemarrow aplasia, in two cases following infective hepatitis. The fetal liver graft was done after stopping other treatments and after conditioning with cyclophosphamide. The fetuses used were aged between 10 and 18 weeks, and the fetal cells were injected intravenously. Two of the patients died of infections, one on the 44th day and the second on the 62nd day. The third patient was alive 26 months after the graft. There was no evidence of bone-marrow conversion to donor type, although the patient is now in a stable haematological state. The fourth patient shows a partial haematological reconstitution, which is autologous, but this child also received steroids and a graft of stem cells from the mother.

The interpretation of the results on these cases is very difficult, and so it is impossible to know what part was played by the fetal liver graft in the two cases where there was a partial reconstitution. Nevertheless it appears that these two cases justify the continuation of such attempts at reconstitution in cases where suitable donors are not available.

\section{Research in the Fetal Tissue Bank}

Throughout the years the biology of fetal cells has been studied in the Tissue Bank particularly, but not exclusively, in tissues that are relevant to transplantation.

\section{RED CELL ANTIGENS}

When a fetus provides a potential source of haemopoietic cells it is important to be able to determine the blood groups of the fetus so that the red cells of the recipient can be examined for the presence of donor cells.

In 1962 blood from 39 fetuses was tested for the 
ABO blood groups by Constandoulakis and Kay. ${ }^{34}$ They found that the A and B antigens are readily detectable but that no distinction between the A1 and $A 2$ antigens could be made. The $A$ and $B$ antigens of fetal red cells were found to be weaker than those of adults in absorptive power, and there was no increase in antigenic strength during fetal life. The next year Constantoulakis et al. ${ }^{35}$ reported that in fetal life the A2 gene is expressed as a phenotype similar to $A_{x}$ in adults, the red cells being agglutinated weakly by anti-A obtained from group $B$ donors but strongly by anti-A from group $\mathrm{O}$ donors. They also showed that the $\mathrm{H}$ antigen is expressed on fetal cells of all ABO groups and, although weaker than in adults, the relationship to the $A$ and $B$ antigens is the same. Concerning the antigenic strength of fetal antigens an interesting observation had been made on the $\mathbf{P}$ blood group system by Ikin et al. ${ }^{36}$ who found that younger fetuses were more frequently and more strongly $\mathbf{P}_{1}$ than were older fetuses.

Others have shown that the $\mathbf{M N}$, Rhesus, $\mathbf{L u}^{\mathrm{a}}$, Kell, Duffy, and Kidd antigens can be detected on fetal red cells. ${ }^{37}$ Therefore when blood is available, fetal red cells can be typed without difficulty. When disrupted fetuses are being used, a blood sample cannot be obtained but a suspension of haemopoietic cells can be prepared from fetal liver from which at least the ABO group can be determined. ${ }^{38}$

HLA ANTIGENS

The developments in the understanding of the HLA system, which have led to such advances in the choice of suitable donors for bone-marrow transplantation, raise the possibility of selecting donors when using fetal tissues. In order to do this it is essential to be able to determine the HLA type of the donor fetus.

If blood is available, fetal lymphocytes can be typed in the same way as those of adults.

We have shown that fetal fibroblasts can also be used as a reliable source of information on the HLA-A and B antigens of the fetus. ${ }^{39}$ The study was done by determining the antigens of lymphocytes and fibroblasts from the same fetus. Correlations were found to be sufficiently good to warrant the use of fibroblasts in the determination of the HLAantigens of disrupted fetuses, particularly if cultures from more than one tissue were tested, for example, lung and skin.

\section{FETAL CHROMOSOMES}

After transplantation the presence of donor cells in the recipient can be identified by using the chromosomes of dividing lymphocytes as a marker for the origin of the cell. The easiest way to exploit the technique is when donor and recipient are of different sex. Applying the technique to another problem, Kay and Margoles ${ }^{40}$ looked for transplacental passage of maternal lymphocytes in male fetuses. They did not find any female cells among 895 examined from 33 male fetuses.

The sex of a disrupted fetus can be determined by looking for sex chromatin or examining the chromosomes in fibroblasts grown in tissue culture.

ALPHA-FETOPROTEIN (AFP)

Many workers use fetal tissue from the Bank in their studies of oncofetal antigens. Lawler and $\mathrm{Nash}^{41}$ showed that fetal skin and muscle was a rich source of AFP, the highest yields being given by fetuses up to 16 weeks menstrual age. Antibodies suitable for radioimmunoassay were prepared by immunising rabbits with concentrates from this source.

\section{HYDATIDIFORM MOLES}

Hydatidiform moles can be classified into two entities, complete and partial mole, each of which has distinct pathological and genetic features. The complete mole is characterised by cystic swelling and gross trophoblastic proliferation in the absence of any evidence of fetal development. 4243 By chromosome analysis these have been shown to be almost always XX and to be entirely androgenetic in origin, that is, the chromosome complement comes entirely from the male parent with no genetic representation of the female genome.44-46 On the other hand, a partial mole shows focal trophoblastic hyperplasia, a range of normal to swollen villi, and, most important, it is associated with the presence of a fetus at some stage. Genetically, partial moles are triploid, and there is a chromosomal contribution from the female parent. ${ }^{47}$

Between August 1978 and the end of July 1980, 3426 disrupted fetuses obtained from pregnancies terminated by the suction method were collected by the Fetal Tissue Bank. Among these were three hydatidiform moles, of which two were diagnosed as complete and one as partial mole. This incidence of molar pregnancy of 1 in 1142 is somewhat higher than the frequency usually quoted for Caucasians. ${ }^{48}$ These early therapeutic abortions were all examined macroscopically for the presence of molar changes. Therefore it is possible that the higher estimate of the frequency of hydatidiform mole is correct. Molar pregnancies among spontaneous abortions that are not examined by medical personnel may escape diagnosis.

The Fetal Tissue Bank staff are also participating in an elective study of hydatidiform moles. ${ }^{49}$ Chromosomal polymorphisms and biochemical genetic markers are being used to study the genetic origin of complete and partial moles. So far we have 
found that complete moles are $\mathrm{XX}$ and genetically homozygous for the male contribution. Partial moles, on the other hand, have been found to be triploid, to show evidence of maternal contribution, and to have arisen by dispermy or failure at the first paternal meiotic division.

The study of moles is being made because of our interest in premalignant conditions. Under a registration scheme devised by the Department of Health and Social Security and the Royal College of Obstetricians and Gynaecologists, patients are followed up after evacuation of a molar pregnancy, and subsequent trophoblastic activity is monitored by measuring levels of human chorionic gonadotrophin. ${ }^{50}$ Thus, in the elective study, we have the opportunity to relate the data on the hydatidiform mole to the clinical outcome. In the United Kingdom, up to $10 \%$ of patients require treatment with chemotherapy because of persistent trophoblastic activity, and about one-third of them are likely to have choriocarcinoma. ${ }^{51}$ Although most patients who require treatment after a molar pregnancy have had a complete mole, there is evidence that treatment may be required after a partial mole. ${ }^{52}$ Among 58 hydatidiform moles studied at the Royal Marsden Hospital between July 1978 and June 1980, 44 were complete and 14 partial. At the time of writing (August 1980), six patients have required treatment and all of these had complete moles.

\section{The future of the Tissue Bank}

There is no doubt that fetal tissue will have applications in service and research work for many years to come. If obstetric practice does not change radically, then the Fetal Tissue Bank should be able to supply the tissues that are required. The needs of virologists are likely to continue at least at the present level for the foreseeable future because human fetal cell cultures are the tissues of choice for the isolation of viruses and the preparation of vaccines. Oncologists continue to require fetal tissue to help sort out neoantigens from development ones. The requests for tissue from molecular biologists are continually increasing. Apart from the present sources in the hydatidiform moles we have the possibility of supplying characterised homozygous human cells. Finally, in supplying organs for transplantation, we are considering the possibility of creating a store of cryopreserved, tissue-typed cells to prepare for the era of matched fetal tissue transplants.

At present the Fetal Tissue Bank is operated by two part-time medical personnel, Dr MJ Allan and Dr L Wong; a scientist, Miss RA Fisher; a junior technician, a porter, and a clerk. Mr AB Hockley, chief technician in the Department of Cytogenetics and Immunology, has contributed to the operation of the Bank for many years. Among the staff who worked both with me and with Dr HEM Kay are Dr B Markowski, Dr C Margoles, and Mrs DL Boyd. I am deeply indebted to all the past and present staff.

The work of the Bank would not be possible without the cooperation of many obstetricians and their staff, and of the director and staff of the London Private Nursing Homes. Those who are working, or have worked, in the Bank are most grateful to them all.

I thank Dr L Wong for suggestions and criticisms of the manuscript, and Miss P Leach for helping me to prepare it.

\section{References}

1 Markowski B, Lawler SD. Use of early fetal tissues obtained from suction termination of pregnancy. Lancet $1977 ; 1: 186-8$.

2 The use of fetuses and fetal material for research. Report of the Advisory Group, Department of Health and Social Security, Scottish Home and Health Department, Welsh Office. London: Her Majesty's Stationery Office, 1972.

s Shepard TH. Growth and development of the human embryo and fetus. In: Endocrine and genetic diseases of childhood and adolescence, 2nd edn. Ed LI Gardner. Philadelphia, London, Toronto: WB Saunders Co, 1975.

4 Miller JFAP. Immunological function of the thymus. Lancet 1961;2:748-9.

- Miller JFAP. Effect of neonatal thymectomy on the immunological responsiveness of the mouse. Proc Royal Soc 1962;156:415-28.

- Kay HEM, Playfair JHL, Wolfendale M, Hopper PK. Nature 1962;196:238-40.

${ }^{7}$ Bruton OC. Agammaglobulinemia. Pediatrics 1952;9:722-8.

8 Glanzmann E, Riniker P. Essentielle Lymphocytophthise. Ein neues Krankenheitsbild aus der Säuglingspathologie. Ann Paediat (Basel) 1950;175:1-32.

- Hitzig WH, Kay HEM, Cottier H. Familial lymphopenia with agammaglobulinaemia. An attempt at treatment by implantation of foetal thymus. Lancet 1965;2:151-4.

${ }^{10}$ Rosen FS, Gitlin D, Janeway CA. Alymphocytosis, agammaglobulinaemia, homografts, and delayed hypersensitivity: study of a case. Lancet $1962 ; 2: 380-1$.

11 Harboe M, Pande H, Brandtzaeg P, Tveter KJ, Hjort PF. Synthesis of donor type $\gamma \mathrm{G}$-globulin following thymus transplantation in hypo- $\gamma$-globulinaemia with severe lymphocytopenia. Scand J Haematol 1966;3:351-74.

12 Hong R, Cooper MD, Allan MJG, Kay HEM, Meuwissen $H$, Good RA. Immunological restitution in lymphopenic immunological deficiency syndrome. Lancet 1968;1: 503-6.

${ }^{13}$ DiGeorge AM. Congenital absence of the thymus and its immunologic consequences: Concurrence with congenital hypoparathyroidism. In: Immunologic deficiency diseases in man. Ed D Bergsma. Birth Defects Original Article Series, IV, 116-23. The National Foundation-March of Dimes.! 1968.

${ }^{14}$ Harington $H$. Absence of the thymus gland. London Medical Gazette 1829;3:314-5.

${ }^{15}$ August CS, Rosen FS, Filler RM, Janeway CA, Markowski B, Kay HEM. Implantation of a foetal thymus, restoring immunological competence in a patient with thymic 
aplasia (DiGeorge's syndrome). Lancet 1968;2:1210-1.

${ }^{16}$ Cleveland WW, Fogel BJ, Brown WT, Kay HEM. Foetal thymic transplant in a case of DiGeorge's syndrome. Lancet 1968;2:1211-4.

17 August CS, Berkel AI, Levey RH, Rosen FS, Kay HEM. Establishment of immunological competence in a child with congenital thymic aplasia by a graft of fetal thymus. Lancet 1970;1:1080-3.

${ }^{18}$ Cleveland WW. Immunologic reconstitution in the DiGeorge syndrome by fetal thymic transplant. In: Immunodeficiency in man and animals. Ed D Bergsma Birth Defects Original Article Series, XI, 352-6. The National Foundation-March of Dimes. 1975.

${ }^{19}$ Kay HEM. Foetal thymus transplants in man. In: Ontogeny of acquired immunity. A Ciba Foundation Symposium (23-25 November 1971), Amsterdam: Elsevier-Excerpta Medica-North-Holland, 249-60.

${ }^{20}$ Foroozanfar N, Yamamura M, Watson G, Weaver P, Belton EM, Lawler S, Hobbs JR. Successful thymus graft for T-cell deficiency in a 6-year-old boy. $\mathrm{Br} \mathrm{Med}$ $J$ 1975;1:314-5.

" Goldstein AL, Guha A, Zatz MM, Hardy MA, White A. Purification and biological activity of thymosin, a hormone of the thymus gland. Proc Natl Acad Sci USA 1972;69:1800-3.

${ }^{22}$ Goldstein AL, Thurman GB, Cohen GH, Hooper JA. Thymosin: chemistry, biology and clinical application. In: Biological activity of thymic hormones. Ed DW Van Bekkum. Rotterdam: Kookyer Scientific Publications, 1975;173-97.

${ }^{23}$ Wara DW, Ammann AJ. Activation of T-cell rosettes in immunodeficient patients by thymosin. Ann NY Acad Sci 1975;249:308-15.

${ }^{24}$ Löwenberg B, Vossen JMJJ, Dooren LJ. Transplantation of fetal liver cells in the treatment of severe combined immunodeficiency disease. Blut 1977;34:181-95.

${ }^{25}$ Giblett ER, Anderson JE, Cohen F, Pollara B, Meuwissen $\mathrm{HJ}$. Adenosine-deaminase deficiency in two patients with severely impaired celullar immunity. Lancet 1972 ; 2:1067-9.

${ }^{26}$ Polmar SH, Wetzler EM, Stern RC, Hirschhorn R. Restoration of in-vitro lymphocyte responses with exogenous adenosine deaminase in a patient with severe combined immunodeficiency. Lancet 1975;2:743-6.

27 Keightley RG, Lawton AR, Cooper MD. Successful fetal liver transplantation in a child with severe combined immunodeficiency. Lancet 1975;2:850-3.

${ }^{2 *}$ Ackeret C, Pluss HJ, Hitzig WH. Hereditary severe combined immunodeficiency and adenosine deaminase deficiency. Pediatr Res 1976;10:67-70.

${ }^{29}$ Buckley RH, Whisnant JK, Schiff RI, Gilbertsen RB, Huang AT. Platt MS. N Engl J Med 1976;294:107681 .

30 Biggar WD, Park B, Niosi P, Yunis EJ, Good RA. Bone marrow transplantation in combined immunodeficiency disease. In: Tissue typing and organ transplantation. Ed EJ Yunis, RR Gatti, BD Amos. New York and London: Academic Press, 1973.

"3ahwa R, Pahwa S, Good RA, Incefy GS, O'Reilly RJ. Rationale for combined use of fetal liver and thymus for immunological reconstitution in patients with variants of severe combined immunodeficiency. Proc Natl Acad Sci USA 1977;74:3002-5.

${ }^{32}$ Bodley Scott R, Matthias JQ, Constandoulakis M, Kay
HEM, Lucas PF, Whiteside JD. Hypoplastic anaemia treated by transfusion of foetal haemopoietic cells. Lancet $1961 ; 2: 1385-8$.

${ }^{33}$ Harousseau JL, Devergie A, Lawler S, Gluckman E. Schaison G. Implant of fetal liver in severe bone marrow aplasia. Nouv Rev Fr Hematol. Société Française d'Hématologie-Résumés du Congrès de Poitiers, May 1980.

${ }^{34}$ Constandoulakis M, Kay HEM. A and B antigens of the human foetal erythrocyte. Br J Haematol 1962;8:57-63.

${ }^{35}$ Constantoulakis M, Kay HEM, Giles CM, Parkin DM. Observations on the $\mathbf{A}_{2}$ gene and $\mathbf{H}$ antigen in foetal life. Br J Haematol 1963;9:63-7.

${ }^{36}$ Ikin EW, Kay HEM, Playfair JHL, Mourant AE. $P_{1}$ antigen in the human foetus. Nature 1961;192:883.

${ }^{37}$ Race RR, Sanger E. Blood groups in man. 6th edn. Oxford, London, Edinburgh, Melbourne: Blackwell Scientific Publications, 1975.

${ }^{38}$ Wong L. Unpublished observations. 1980.

${ }^{39}$ Singh SPN, Vyramuthu N, Margoles C, Lawler SD. HLA typing of human fetal fibroblasts. Transplantation 1979: 28:262-3.

${ }^{40}$ Kay HEM, Margoles C. Chromosomes of human fetal lymphocytes: frequency of abnormalities and absence of maternal cells. Lancet 1971;2:733-5.

11 Lawler SD, Nash SG. Alpha-fetoprotein in fetal skin and muscle. Br J Obstet Gynaecol 1977;84:51-4.

${ }^{42}$ Vassilakos P, Riotton G, Kajii T. Hydatidiform mole: two entities. A morphologic and cytogenetic study with some clinical considerations. Am J Obstet Gynecol 1977;127: 167-70.

${ }^{43}$ Szulman AE, Surti U. The syndromes of hydatidiform mole. II. Morphologic evolution of the complete and partial mole. Am J Obstet Gynecol 1978;132:20-7.

${ }^{4}$ Kajii T, Ohama K. Androgenetic origin of hydatidiform mole. Nature 1977;268:633-4.

45 Jacobs PA, Hassold TJ, Matsuyama AM, Newlands IM. Chromosome constitution of gestational trophoblastic disease. Lancet 1978; 2:49.

${ }^{46}$ Wake N, Takagi N, Sasaki N. Androgenesis as a cause of hydatidiform mole. J Natl Cancer Inst 1978;60:51-7.

${ }^{4}$ Szulman AE, Surti U. The syndromes of hydatidiform mole. I. Cytogenetic and morphological correlations. Am J Obstet Gynecol 1978;131:665-71.

48 Bagshawe KD, Lawler SD. Choriocarcinoma. In: Cancer epidemiology and prevention. Ed D Schottenfeld. J Fraumeni Jr. Philadelphia, London, Toronto: WB Saunders Co, in press.

${ }^{49}$ Lawler SD, Pickthall VJ, Fisher RA, Povey S, Wyn Evans $M$, Szulman AE. Genetic studies of complete and partial hydatidiform moles. Lancet 1979;2:580.

${ }^{50}$ A nonymous. New follow-up of hydatidiform mole. $\mathrm{Br}$ Med J 1972 ;iv :685-6.

${ }^{51}$ Stone M, Dent J, Kardana A, Bagshawe KD. Relationship of oral contraception to development of trophoblastic tumour after evacuation of hydatidiform mole. $\mathrm{Br} J$ Obstet Gynaecol 1976;83:913-6.

${ }^{52}$ Stone M, Bagshawe KD. Hydatidiform mole: two entities. Lancet 1976;1:535-6.

Requests for reprints to: Dr Sylvia Lawler, Department of Cytogenetics and Immunogenetics, The Royal Marsden Hospital, Fulham Road, London SW3 6JJ. 